\title{
A mountain of millipedes V: three new genera of Odontopygidae from the Udzungwa mountains, Tanzania (Diplopoda, Spirostreptida, Odontopygidae)
}

\author{
Henrik ENGHOFF \\ Natural History Museum of Denmark, University of Copenhagen, \\ Universitetsparken 15, DK-2100 København Ø, Denmark. \\ Email: henghoff@snm.ku.dk \\ urn:1sid:zoobank.org:author:FB09A817-000D-43C3-BCC4-2BC1E5373635
}

\begin{abstract}
Three new genera of Odontopygidae are described, all based on new species from the Udzungwa mountains, Tanzania, and all monotypic: Casuariverpa gen. nov. (type species: C. scarpa gen. et sp. nov.), Yia gen. nov. (type species: Y. geminispina gen. et sp. nov.), and Utiliverpa gen. nov. (type species: $U$. decapsulatrix gen. et sp. nov.). Similarities and differences between the new genera and other genera are discussed.
\end{abstract}

Keyword. Eastern Arc, taxonomy, new genera, new species.

Enghoff H. 2016. A mountain of millipedes V: three new genera of Odontopygidae from the Udzungwa mountains, Tanzania (Diplopoda, Spirostreptida, Odontopygidae). European Journal of Taxonomy 221: 1-17. http://dx.doi. org/10.5852/ejt.2016.221

\section{Introduction}

This is the fifth in a series of articles about the millipedes, especially the endemic Afrotropical family Odontopygidae, of the Udzungwa Mountains, Tanzania. For general information on the Odontopygidae and the Udzungwa Mountains see the first article in the series (Enghoff 2014). See also Enghoff \& Frederiksen (2015) and Enghoff (2016a, 2016b).

In the present contribution, three new, monotypic genera and their type species are described.

\section{Material and methods}

The material for this article comes mostly from the zoological collections of the Natural History Museum of Denmark, University of Copenhagen (ZMUC). These specimens were collected during field trips by ZMUC staff and students. A specimen from Virginia Museum of Natural History (VMNH) was also examined. All specimens are kept in $70 \%$ alcohol.

Specimens were examined in alcohol under a stereo microscope. Specimens for scanning electron microscopy (SEM) were transferred to $96 \%$ ethanol, then to acetone, air-dried, mounted on aluminium 
stubs or on pieces of flexible aluminium tape and in turn mounted on stubs, coated with platinumpalladium and studied in a JEOL JSM-6335F scanning electron microscope.

As in previous articles in this series, only adult males are considered. A total of 14 adult males of the three new species were examined. Fig. 1 shows the Udzungwa localities where the new species described here were collected. Fig. 2 gives the body size (body diameter/number of podous rings) of males of the new species.

See Enghoff (2014) for the description standards used.

\section{Abbreviations for morphological terms used in the descriptions and on illustrations}

$$
\begin{aligned}
\text { all } & =\text { apical lateral lobe of coxa } \\
b a & =\text { basomere } \\
c u & =\text { cucullus } \\
e g & =\text { efferent groove } \\
l p & =\text { lateral coxal process }
\end{aligned}
$$

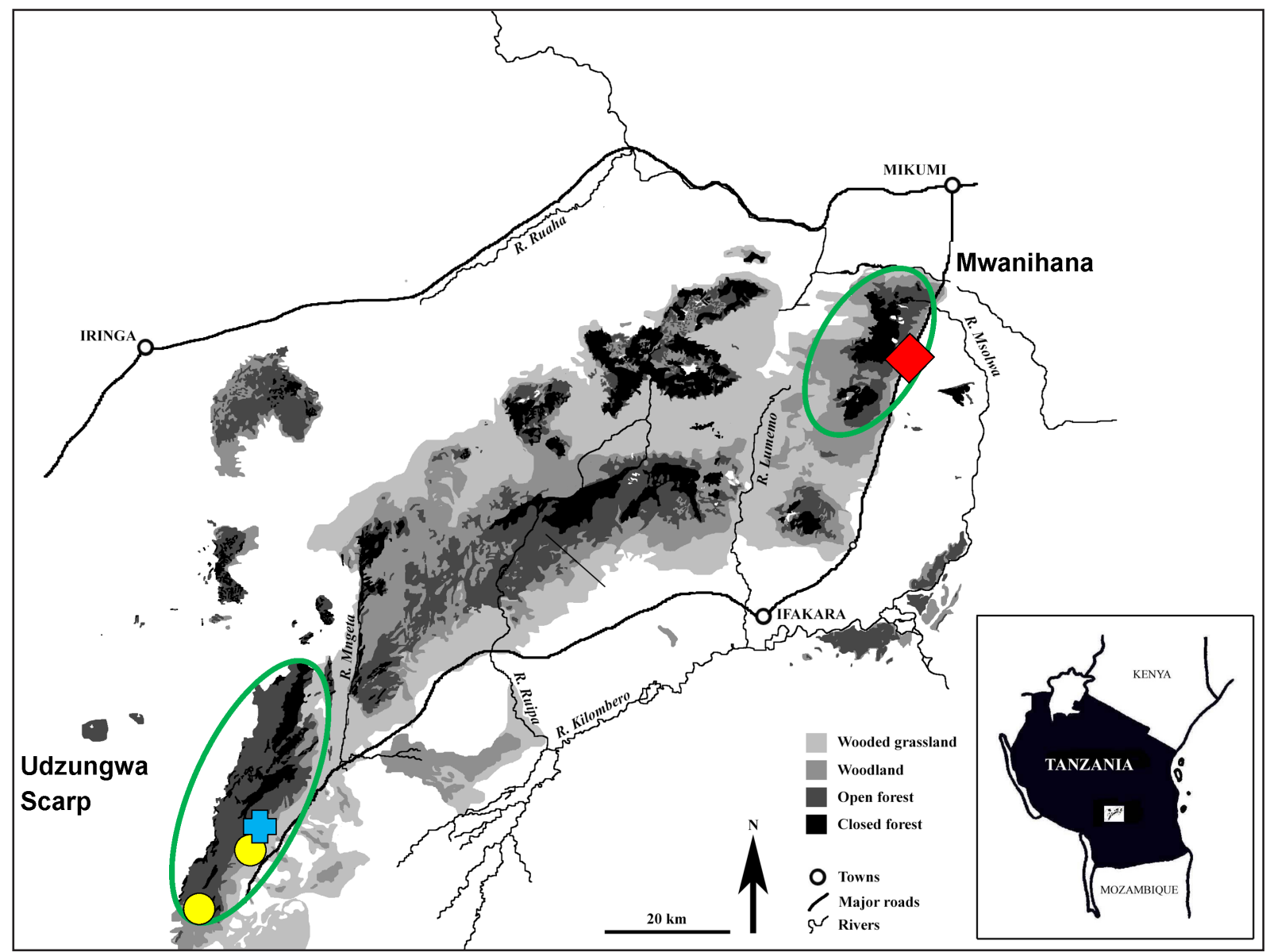

Fig. 1. Map of the Udzungwa Mountains, showing the collecting localities for Casuariverpa scarpa gen. et sp. nov. (yellow dots), Yia geminispina gen. et sp. nov. (blue cross), and Utiliverpa decapsulatrix sp. nov. (red diamond). Based on fig. 1 in Marshall et al. (2010). 


$$
\begin{aligned}
m b p & =\text { metaplical bifid process } \\
m f & =\text { metaplical flange } \\
m p & =\text { metaplica } \\
m s & =\text { metaplical shelf } \\
m s p & =\text { metaplical spine } \\
p n & =\text { posttorsal narrowing } \\
p p & =\text { proplica } \\
p r l & =\text { proplical lobe } \\
p s & =\text { proximal solenomeral spine. } \\
s l m & =\text { solenomere } \\
t d p & =\text { telomeral distal process } \\
t f & =\text { telomeral furrow } \\
t l m & =\text { telomere } \\
t r & =\text { telomeral ridge } \\
t s 1, t s 2 & =\text { telomeral spines } \\
t s s & =\text { telomeral subapical spike } \\
t t & =\text { torsotope }
\end{aligned}
$$

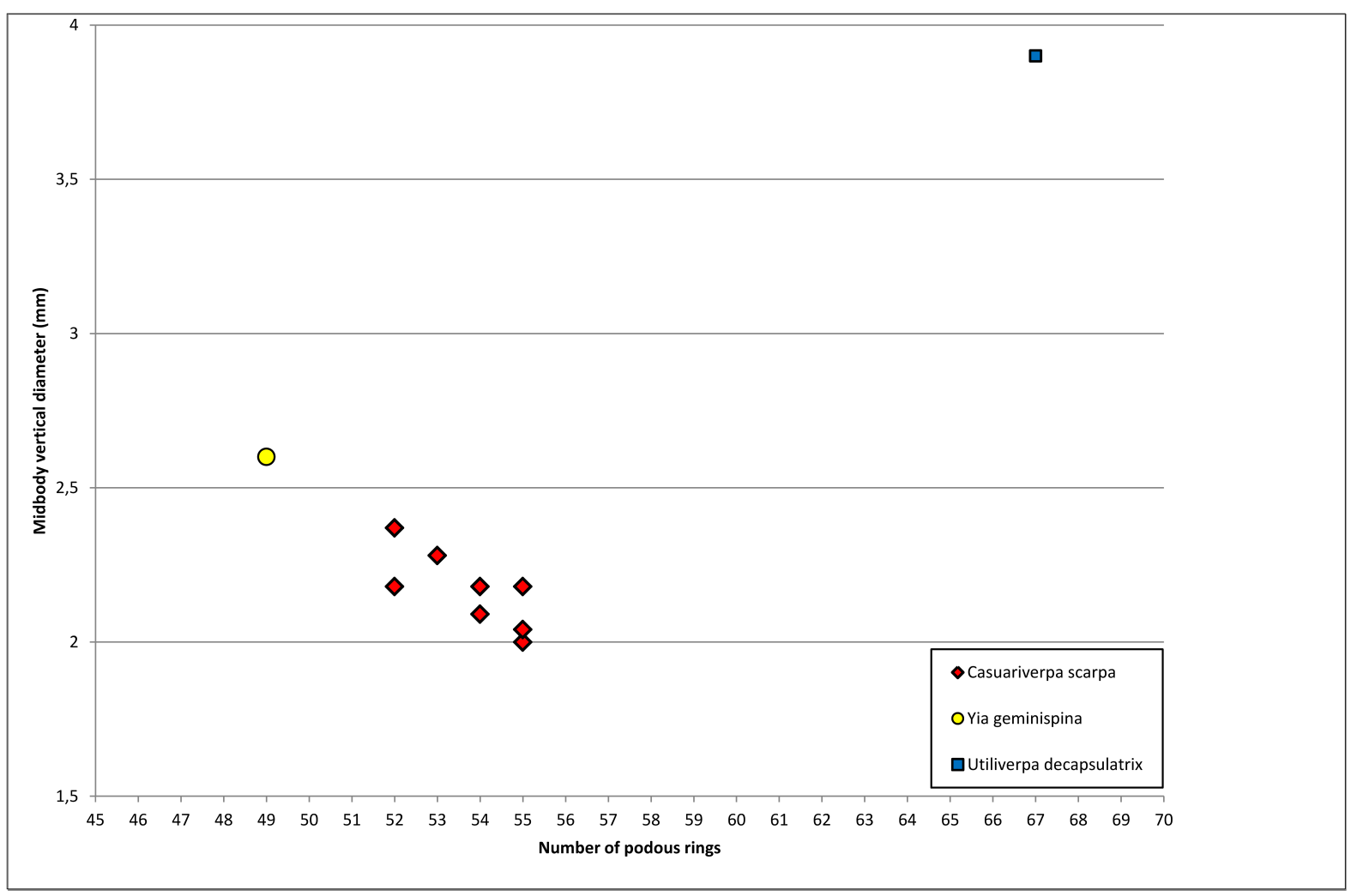

Fig. 2. Body size (body diameter/number of podous rings) of males of the new species described here. 


\section{Results}

Class Diplopoda Blainville-Gervais, 1844

Order Spirostreptida Brandt, 1833

Family Odontopygidae Attems, 1909

Subfamily Archepyginae Manfredi, 1939

Tribe Prionopetalini Hoffman, 1991

Casuariverpa gen. nov.

urn:1sid:zoobank.org:act:5071EA1A-F2FB-4A8C-AE0C-4F18EA27C973

\section{Type species}

Casuariverpa scarpa gen. et sp. nov.

\section{Other included species}

None.

\section{Diagnosis}

A genus of Odontopygidae-Prionopetalini characterized by: anal valves with a well-developed dorsal spine, a similarly well-developed ventral spine and strongly protruding setiferous tubercles - male body ring seven with large ventral lobes - limbus very broad, with a simply denticulate margin - ventral postfemoral and tibial pads on some male legs - gonopod coxa simple, metaplica $(\mathrm{mp})$ with a subapical basad spine $(m s p)$ - gonopod telopodite with a compact torsotope $(t t)$ - no pretorsal or torsal spines/ processes - a pronounced posttorsal narrowing $(p n)$ without spines - a division of the telopodite into solenomere $(\mathrm{slm})$ and telomere $(\mathrm{tlm})$ immediately distal to posttorsal narrowing - solenomere whiplike, with a very long accessory spine ( $p s)$ branching off near its base and with a small subdistal lobe telomere simple, with a longitudinal ridge on concave side enveloping solenomere, distally expanded, with micro-spinose fields basally and distally.

\section{Etymology}

From Latin Casuaria, "cassowary", and "verpa", penis. Refers to the shape of the solenomere tip which is somewhat reminiscent of the head profile of the Australian cassowary (Casuarius casuarius (Linnaeus, 1758)). Gender feminine.

\section{Remarks}

In the key of Kraus (1966), C. scarpa gen. et sp. nov. runs to Trichochaleponcus Attems, 1928 (couplet 21). They key character for this genus is the very broad limbus (which is, however, paralleled in certain other odontopygids, e.g., Kompsoprium firmosum Kraus, 1960 (Kraus 1960: fig. 69)). Casuariverpa scarpa gen. et sp. nov. also agrees with Trichochaleponcus species in some other characters, but there are differences enough, at least vis-a-vis the type species of Trichochaleponcus, that a new genus is warranted, cf. Enghoff (2016a). Thus, Casuariverpa gen. nov. has strongly protruding setiferous tubercles and an exceptionally well-developed ventral spine on the anal valves, its gonopod coxa has no lateral process or spine at mid-length, its gonopod telopodite has no spine between torsotope and posttorsal narrowing, the solenomere has no second basal spine in addition to the very long one, and the telomere is expanded distally instead of being strongly attenuate. See Table 1. 
Table 1. (continued on next page) Comparison of Casuariverpa scarpa gen. et sp. nov. and Yia geminispina gen. et sp. nov. with Trichochaleponcus Attems, 1928 and its constituent species. Information on Trichochaleponcus taken from the cited papers.

\begin{tabular}{|c|c|c|c|c|c|c|}
\hline Character & $\begin{array}{l}\text { Casuariverpa } \\
\text { scarpa } \\
\text { gen. et } \\
\text { sp. nov. }\end{array}$ & $\begin{array}{c}\text { Trichochaleponcus } \\
\text { general - } \\
\text { (Kraus 1960) }\end{array}$ & $\begin{array}{c}\text { T. fissicirratus } \\
\text { - (Attems } \\
\text { 1914) } \\
\text { (type species) }\end{array}$ & $\begin{array}{l}\text { T. spinifer } \\
- \text { (Attems } \\
\text { 1938) }\end{array}$ & $\begin{array}{c}\text { T. lomelaensis } \\
\text { - (Kraus } \\
\text { 1960) }\end{array}$ & $\begin{array}{c}\text { Yia } \\
\text { geminispina } \\
\text { gen. et } \\
\text { sp. nov. }\end{array}$ \\
\hline \multicolumn{7}{|c|}{ NON-GONOPOD CHARACTERS } \\
\hline $\begin{array}{l}\text { anal valves, } \\
\text { marginal ridge }\end{array}$ & $\begin{array}{l}\text { not separated } \\
\text { from median } \\
\text { margin }\end{array}$ & $\begin{array}{l}\text { separated from } \\
\text { median margin by } \\
\text { deep depression }\end{array}$ & $\begin{array}{l}\text { separated from } \\
\text { median margin } \\
\text { by depression }\end{array}$ & $\begin{array}{l}\text { not separated } \\
\text { from median } \\
\text { margin }\end{array}$ & $\begin{array}{l}\text { separated from } \\
\text { median margin } \\
\text { by shallow } \\
\text { depression }\end{array}$ & $\begin{array}{l}\text { not separated } \\
\text { from median } \\
\text { margin }\end{array}$ \\
\hline $\begin{array}{l}\text { anal valves, } \\
\text { setiferous } \\
\text { tubercles }\end{array}$ & $\begin{array}{l}\text { protruding in } \\
\text { lateral view }\end{array}$ & no info & $\begin{array}{l}\text { forming } \\
\text { "ravelins" }\end{array}$ & no info & no info & $\begin{array}{l}\text { forming } \\
\text { small } \\
\text { "ravelins" }\end{array}$ \\
\hline $\begin{array}{l}\text { anal valves, } \\
\text { dorsal spine }\end{array}$ & very big & no info & very stout & no info & present & big \\
\hline $\begin{array}{l}\text { anal valves, } \\
\text { ventral spine }\end{array}$ & very big & no info & absent & no info & absent & absent \\
\hline limbus & $\begin{array}{l}\text { very broad, } \\
\text { margin } \\
\text { divided into } \\
\text { narrow, blunt- } \\
\text { triangular } \\
\text { processes }\end{array}$ & $\begin{array}{l}\text { very broad, } \\
\text { divided into simple } \\
\text { processes which in } \\
\text { fissicirratus } \text { are each } \\
\text { divided again into } \\
2-6 \text { processes }\end{array}$ & $\begin{array}{l}\text { quite broad, } \\
\text { margin with } \\
\text { simple, narrow } \\
\text { points }\end{array}$ & $\begin{array}{l}\text { very broad, } \\
\text { margin } \\
\text { divided into } \\
2-6 \text {-cusped } \\
\text { processes }\end{array}$ & $\begin{array}{l}\text { unusually } \\
\text { broad, margin } \\
\text { divided } \\
\text { into simple, } \\
\text { pointed- } \\
\text { ligulate } \\
\text { processes }\end{array}$ & $\begin{array}{l}\text { very narrow, } \\
\text { margin with } \\
\text { simple, } \\
\text { narrow points }\end{array}$ \\
\hline \multicolumn{7}{|c|}{ GONOPOD COXA } \\
\hline $\begin{array}{l}\text { with a lateral } \\
\text { spine/process ca } \\
\text { at midlength }\end{array}$ & no & yes & yes & yes & yes & no \\
\hline $\begin{array}{l}\text { metaplica with } \\
\text { basad/mesad } \\
\text { oral process }\end{array}$ & yes & yes & yes & yes & yes & yes \\
\hline \multicolumn{7}{|c|}{ GONOPOD TELOPODITE } \\
\hline $\begin{array}{c}\text { posttorsal, } \\
\text { pre-narrowing } \\
\text { spine }\end{array}$ & no & platelike, expanded & $\begin{array}{l}\text { very short, } \\
\text { blunt }\end{array}$ & no (?) & $\begin{array}{l}\text { platelike, } \\
\text { expanded }\end{array}$ & no \\
\hline $\begin{array}{l}\text { solenomere } \\
\text { with } \\
\text { long side- } \\
\text { branch } \\
\text { ("Tibialdorn") }\end{array}$ & yes & yes & yes & yes & yes & yes \\
\hline $\begin{array}{l}\text { solenomere also } \\
\text { with second } \\
\text { basal spine } \\
\text { ("Tibialdorn") }\end{array}$ & no & yes & yes & no (?) & yes & yes \\
\hline
\end{tabular}




\begin{tabular}{|c|c|c|c|c|c|c|}
\hline Character & $\begin{array}{c}\text { Casuariverpa } \\
\text { scarpa } \\
\text { gen. et } \\
\text { sp. nov. }\end{array}$ & $\begin{array}{c}\text { Trichochaleponcus } \\
\text { general- } \\
\text { (Kraus 1960) }\end{array}$ & $\begin{array}{c}\text { T. fissicirratus } \\
- \text { (Attems } \\
\text { 1914) } \\
\text { (type species) }\end{array}$ & $\begin{array}{l}\text { T. spinifer } \\
-(\text { Attems } \\
\text { 1938) }\end{array}$ & $\begin{array}{l}\text { T. lomelaensis } \\
\text { - (Kraus } \\
\text { 1960) }\end{array}$ & $\begin{array}{c}\text { Yia } \\
\text { geminispina } \\
\text { gen. et } \\
\text { sp. nov. }\end{array}$ \\
\hline $\begin{array}{c}\text { solenomere } \\
\text { with small } \\
\text { subdistal } \\
\text { process/tooth }\end{array}$ & yes & no info & no info & no & yes & no \\
\hline $\begin{array}{l}\text { telomere } \\
\text { distally }\end{array}$ & $\begin{array}{l}\text { expanded, } \\
\text { distal margin } \\
\text { straight }\end{array}$ & no info & $\begin{array}{l}\text { strongly } \\
\text { attenuate, } \\
\text { ending in } \\
\text { very thin, } \\
\text { microtrichose } \\
\quad \text { tip }\end{array}$ & $\begin{array}{c}\text { strongly } \\
\text { attenuate, } \\
\text { ending in } \\
\text { very thin tip }\end{array}$ & $\begin{array}{c}\text { strongly } \\
\text { attenuate, } \\
\text { ending in } \\
\text { spinelike tip }\end{array}$ & $\begin{array}{c}\text { strongly } \\
\text { attenuate, } \\
\text { ending in } \\
\text { very thin tip }\end{array}$ \\
\hline $\begin{array}{l}\text { telomere with } \\
\text { microtrichose/- } \\
\text { spiculose area }\end{array}$ & $\begin{array}{l}\text { basally and } \\
\text { distally }\end{array}$ & yes & distally & $\begin{array}{l}\text { basally and } \\
\text { distally }\end{array}$ & distally & no \\
\hline
\end{tabular}

Casuariverpa scarpa gen. et sp. nov. urn:1sid:zoobank.org:act:F7F88676-2515-47A6-91EE-01FABFE43894

Figs 3-4

\section{Diagnosis}

(redundant, genus monotypic)

\section{Etymology}

The name is a noun in apposition and refers to the Udzungwa Scarp Forest Reserve.

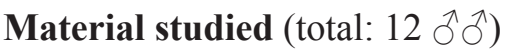

\section{Holotype}

TANZANIA: §̋, Udzungwa Mts, Iringa Region, Udzungwa Scarp Forest Reserve above Chita village, 1050 m, 26-29 Oct. 1984. Pitfall traps in intermediate rain forest, N. Scharff leg. (ZMUC00046998).

\section{Paratypes}

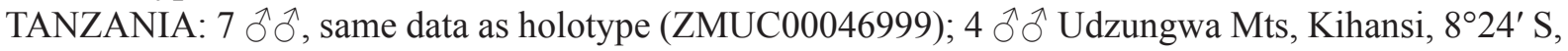
36²1' E, “forest site”, Jun.-Aug.1997, I. Zilihona leg. (ZMUC00047000).

\section{Description (male)}

SizE. Length ca 2⿺辶⿸厃𠄌 $-3 \mathrm{~cm}$, diameter $2.0-2.4 \mathrm{~mm}, 52-55$ podous rings, no apodous rings in front of telson.

Colour. Faded; traces of a broad, light dorsal stripe.

HEAD. Without peculiarities.

Collum. With a marginal and $\sim 3$ submarginal furrows.

BODY RINGS. Almost perfect cylinders, not vaulted; suture straight; ozopores ca three diameters behind suture. 

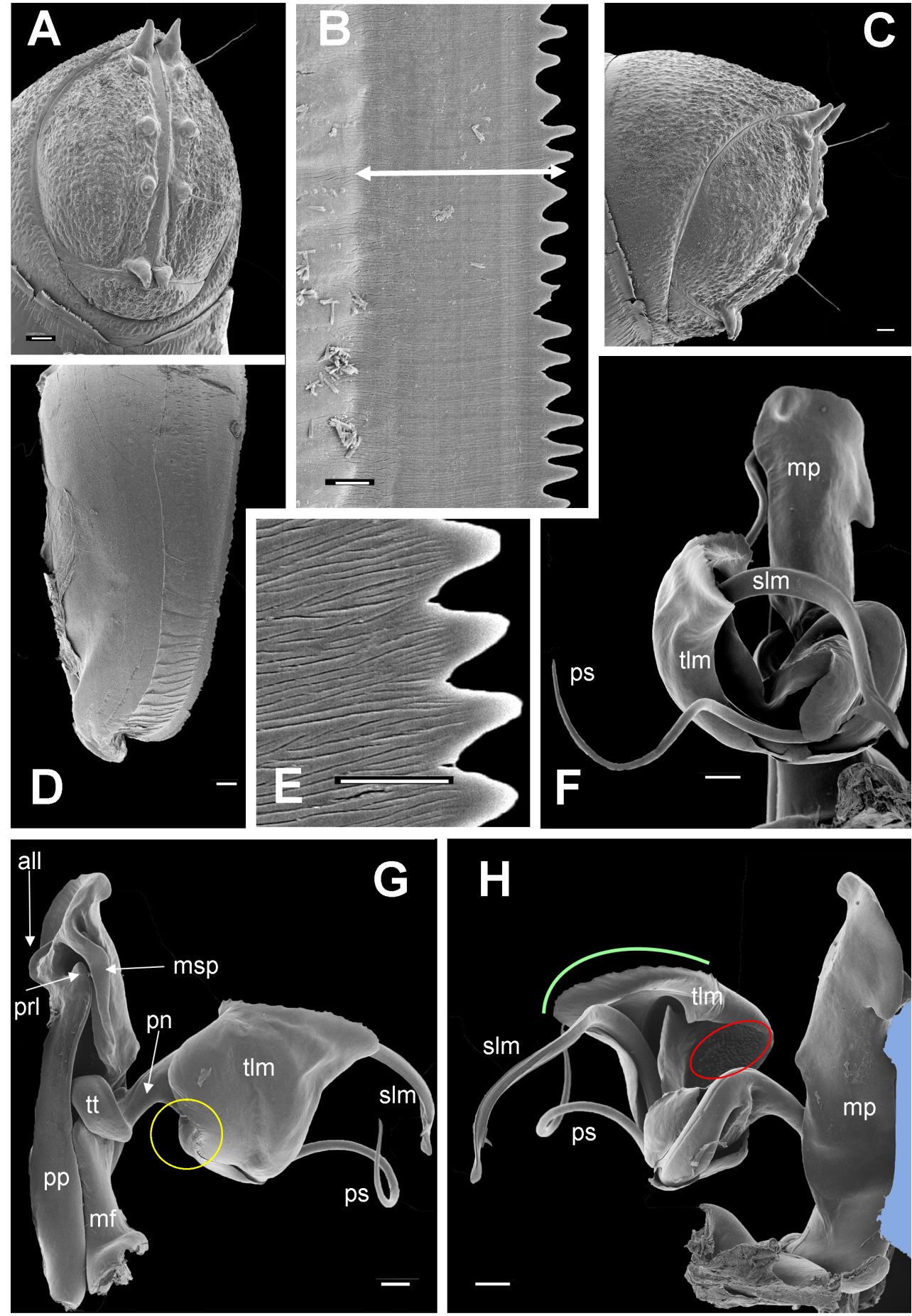

Fig. 3. Casuariverpa scarpa gen. et sp. nov., paratype from Udzungwa Scarp Forest Reserve above Chita village. A, C. Telson. A. Posterior view. C. Lateral view. B. Limbus, the double-headed arrow indicates the extent of the limbus. D. Body ring 7, left lateral view. E. Detail of limbus to show microstriolation. F-G. Left gonopod. F. Mesal view. G. Anterior view, the yellow circle indicates the position of the microspinose field shown in Fig. 4E. H. Posterior view, the red oval indicates the position of the microspinose field shown in Fig. 4E, the green line indicates the distal margin of the telomere; blue colour = mounting tape. Abbreviations: all $=$ apical lateral lobe of coxa, $m f=$ metaplical flange, $m p=$ metaplica, $m s p=$ metaplical spine, $p n=$ post-torsal narrowing, $p p=$ proplica, $p r l=$ proplical lobe, $p s=$ proximal solenomeral spine, $s l m=$ solenomere, $t l m=$ telomere, $t t=$ torsotope. Scales: A, C-D, F-H $=0.1 \mathrm{~mm} ; \mathrm{B}, \mathrm{E}=0.01 \mathrm{~mm}$. 


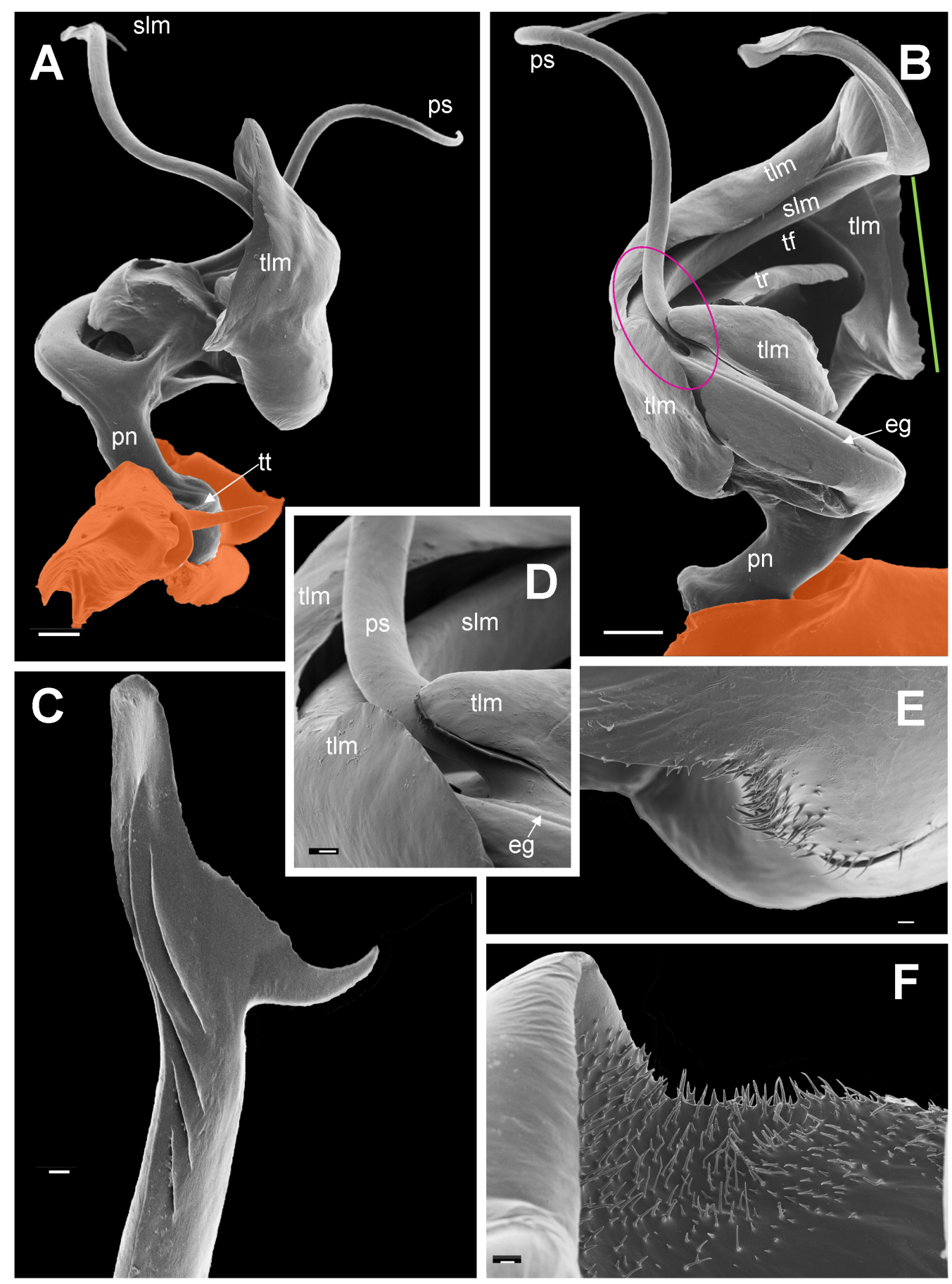

Fig. 4. Casuariverpa scarpa gen. et sp. nov., paratype from Udzungwa Scarp Forest Reserve above Chita village, left gonopod telopodite. A. Apical view, coxal parts in orange colour. B. Basal view, purple oval roughly corresponds to Fig. 4D, coxal parts in orange colour, the green line indicates the distal margin of the telomere. C.Tip of solenomere. D. Origin of proximal solenomeral spine ( $p s$ ) between two basal lobe of telomere $(\mathrm{tlm})$, image roughly corresponding to purple oval on Fig. 4B. E. Micro-spinose field on basal external side of telomere basis, image roughly corresponding to area in yellow circle on Fig. 3G. F. Micro-spinose field on distal part of telomere concavity, image roughly corresponding to area in red oval on Fig. $3 \mathrm{H}$. Abbreviations: $e g=$ efferent groove, $p n=$ post-torsal narrowing, $p s=$ proximal solenomeral spine, $s l m=$ solenomere, $t f=$ telomeral furrow, $t l m=$ telomere, $t r=$ telomeral ridge $t t=$ torsotope. Scales: A-B $=0.1 \mathrm{~mm} ; \mathrm{C}-\mathrm{F}=0.01 \mathrm{~mm}$. 
Anal valves (Fig. 3A, C). Surface, like that of preanal ring and subanal scale, coarsely rugose. Each valve with a long dorsal spine and an almost as long downwards curved ventral spine; marginal rim barely raised, setiferous tubercles strongly protruding in lateral view, but not protruding in a laterad direction.

OzOPOREs. Starting from ring 6 .

LimBus (Fig. 3B, E). Very broad, with simple, rounded-triangular lobes, surface densely microstriolate.

MALE LEgs. With postfemoral and tibial ventral pads in anterior body half, except on first few leg-pairs.

Body RING 7 (Fig. 3D). With large ventral lobes, much larger than usual in the family.

Gonopod COXA (Fig. 3F-H). Slender in anterior view, almost parallel-sided except apically where it has a blunt-triangular lateral expansion (all), giving the coxal tip a sub-triangular outline. Proplica $(p p)$ simple, proplical lobe ( $\mathrm{prl}$ ) not covered by metaplica. Metaplica $(\mathrm{mp})$ with large flange $(\mathrm{mf})$ reaching to level of arculus, distal to arculus closely appressed to proplica, subdistally with a long, slightly sinuous basad spine $(m s p)$.

Gonopod telopodite (Figs 3F-H, 4). Arculus ca 90. Torsotope ( $t t$ ) simple, compact, without processes, partly hidden inside coxal cavity, i.e., the part of the telopodite between arculus and torsotope extremely short. Posttorsal narrowing $(p n)$ without processes or spines. Telopodite just distal to posttorsal narrowing dividing into solenomere and telomere. Solenomere $(\mathrm{slm})$ long, whiplike, longer than telomere, with a very long accessory spine ( $p s)$ branching off near its base; tip of solenomere with a curved, triangularpointed lobe giving the tip a profile somewhat similar to that of a cassowary (see etymology). Telomere $(\mathrm{tlm})$ proximally enveloping base of solenomere, distally expanded, all in all forming a roughly triangular concave plate; concavity with a longitudinal ridge (tr) delimiting a broad furrow $(t f)$ for accommodation of solenomere; distal margin of telomere straight, gently undulate. A micro-spinose field on basal external side of telomere basis (Figs 3G, 4E), another micro-spinose field (Figs 3H, 4F) on distal part of telomere concavity.

\section{Distribution and habitat}

Known only from the two sites in and adjacent to the Udzungwa Scarp Forest Reserve, Udzungwa Mts.

\section{Coexisting species}

Aquattuor stereosathe Enghoff, 2015 was found in the same sample from above Chita as C. scarpa gen. et sp. nov. In addition, A. udzungwensis Enghoff, 2015, Chaleponcus circumvallatus Enghoff, 2014, C. hamerae Enghoff, 2014, C. nikolajscharff Enghoff, 2014 and Yia geminispina gen. et sp. nov. occur in the Udzungwa Scarp Forest Reserve. At Kihansi, Prionopetalum asperginis Enghoff, 2016 was found in the same sample as C. scarpa gen. et sp. nov.

Yia gen. nov. urn:Isid:zoobank.org:act:A986C43A-6B7D-45DB-BD61-FD714D2F53E1

\section{Type species}

Yia geminispina gen. et sp. nov.

\section{Other included species}

None. 


\section{Diagnosis}

A genus of Odontopygidae-Prionopetalini characterized by: a metaplical shelf $(\mathrm{ms})$ with a curved spine ( $m s p$ ) on the coxa (shared with the Chaleponcus dabagaensis group, see Enghoff 2014) - a compact torsotope $(t t)$ - lack of pretorsal or torsal spines/processes - a pronounced posttorsal narrowing ( $p n)$ without spines - a division of the telopodite into solenomere $(\mathrm{slm})$ and telomere $(\mathrm{tlm})$ immediately distal to posttorsal narrowing - a pair of long spines $(t s 1, t s 2)$ emerging from the base of the telomere a slender, whiplike solenomere - a very long, slender distal telomeral process $(t d p)$ with a row of long Y- or I-shaped spikes along one edge and an extensively spinose tip.

\section{Etymology}

The name is an artificial word and refers to the row of Y- and I-shaped spikes on the gonopod telomere (Fig. 6F). To be treated as feminine.

\section{Remarks}

In the key of Kraus (1966) Y. geminispina gen. et sp. nov. runs to Odontopyge Brandt, 1841. As explained by Hoffman (1991) and Enghoff (2016a) this name has been misapplied, and species classified in Odontopyge by pre-1991 authors need to be re-allocated. This is an ongoing process, but the type species of Yia gen. nov. cannot be accommodated in any of the genera which have so far absorbed former Odontopyge species (see Enghoff 2016a). I therefore propose a new genus. None of the still orphaned ex-Odontopyge species share the diagnostic characters of Yia gen. nov., which thus remains monotypic for the time being. Geotypodon heteromodestus (Kraus, 1960) (=Haplothysanus modestus Attems, 1953, preoccupied) shares the double telopodital spine characteristic of Yia gen. nov., but differs strongly in several other characters including the structure of the telomere. A very long, very slender distal telomeral process is found in some other odontopygids, e.g., all species of Allantogonus Attems, 1912 (Kraus 1960) and Prionopetalum Attems, 1909 (VandenSpiegel \& Pierrard 2009; Enghoff 2016b), but these genera differ from Yia gen. nov. in other characters, and no other species has the row of long Y- or I-shaped spikes characteristic of this genus. The metaplical shelf and spine resemble a similar structure in the Chaleponcus dabagaensis group (Enghoff 2014), but in Yia gen. nov. the spine originates between the shelf and the apical metaplical hood, not from the shelf itself as in the $C$. dabagaensis group. Also the apical metaplical cucullus $(\mathrm{cu})$ resembles the $C$. dabagensis group. Yia geminispina gen. et sp. nov. also shows specific similarities with species of the genus Trichochaleponcus Attems, 1928: the general shape of the coxa, the presence of two spines originating at the base of the telomere, and the tip of the telomere being drawn out into a slender arm. Notable differences include the limbus which is very narrow in Yia gen. nov., very broad in Trichochaleponcus, the absence of a posttorsal, pre-narrowing spine as well as of microtrichose areas on the telomere in Yia, and the unique Y-shaped spicules on the telomere tip in Yia. See also Table 1. The peculiar course of the pro-metazonal suture seen in Yia geminispina gen. et sp. nov. has so far not been observed in any other odontopygid.

Yia geminispina gen. et sp. nov. urn:1sid:zoobank.org:act:0861F871-FE89-4563-9C19-5F1A95D2B4C1

Figs 5-6

\section{Diagnosis}

(redundant, genus monotypic)

\section{Etymology}

The name is a composite Latin noun in apposition meaning "twin spine" and refers to the pair of long spines on the telomere. 
Material studied (total: 1 ふ)

\section{Holotype}

TANZANIA: $\widehat{\jmath}$, Udzungwa Mts., Chita Forest Reserve [actually: Udzungwa Scarp F.R.], 1100 m, 25 Oct. 1984, M. Stoltze \& G. Petersen leg. (ZMUC00047001).
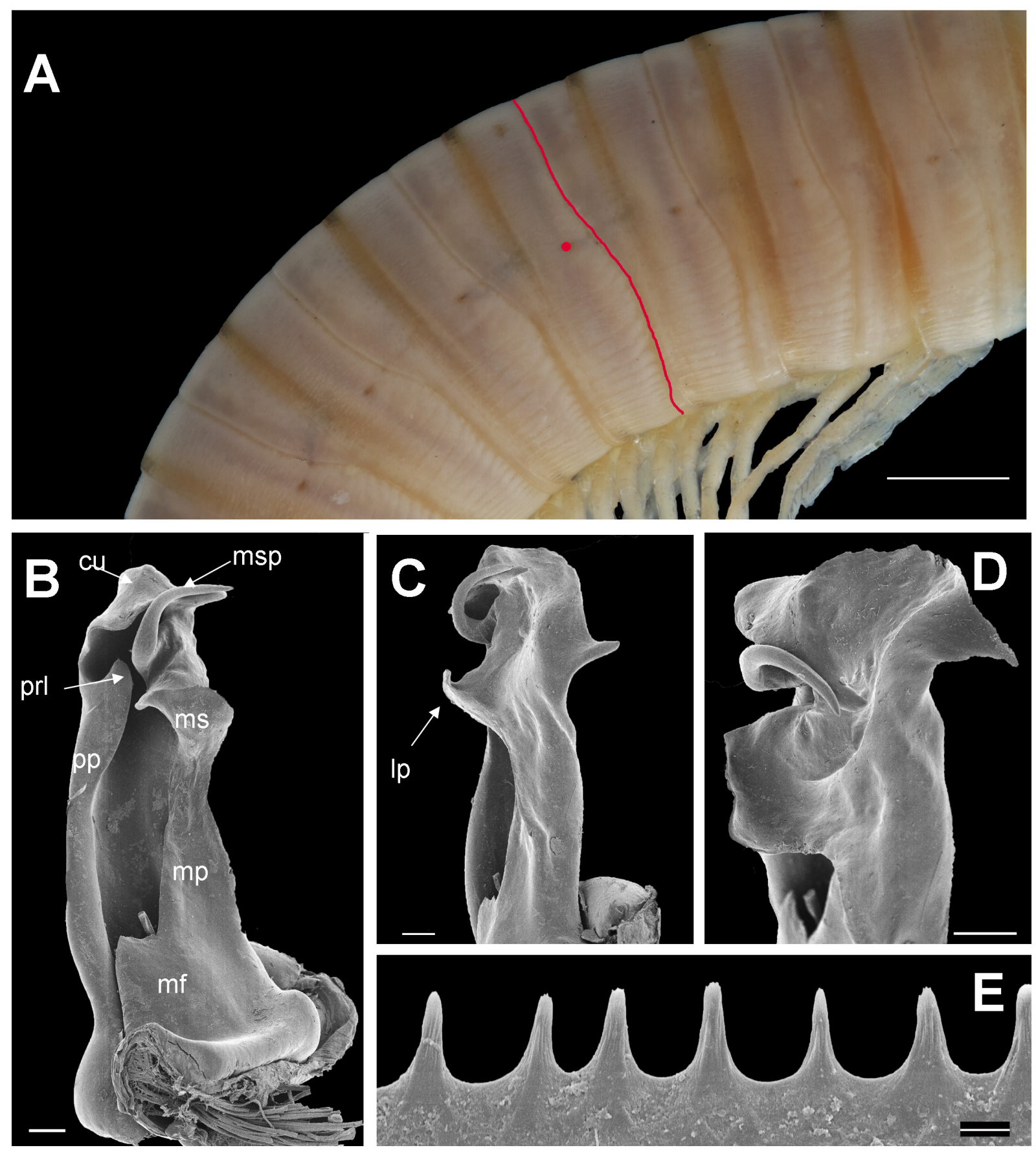

Fig. 5. Yia geminispina gen. et sp. nov., holotype. A. Part of midbody showing the characteristic course of the suture and the position of the ozopore (highlighted in red on one body ring). B-D. Left gonopod coxa. B. Anterior-mesal view. C. Posterior view. D. Mesal view, close-up. E. Limbus. Abbreviations: $c u=$ cucullus, $l p=$ lateral coxal process, $m f=$ metaplical flange, $m p=$ metaplica, $m s=$ metaplical shelf, $m s p=$ metaplical spine, $p p=$ proplica, $p r l=$ proplical lobe. Scales: $\mathrm{A}=1 \mathrm{~mm} ; \mathrm{B}-\mathrm{D}=0.1 \mathrm{~mm}$; $\mathrm{E}=$ $0.005 \mathrm{~mm}$. 

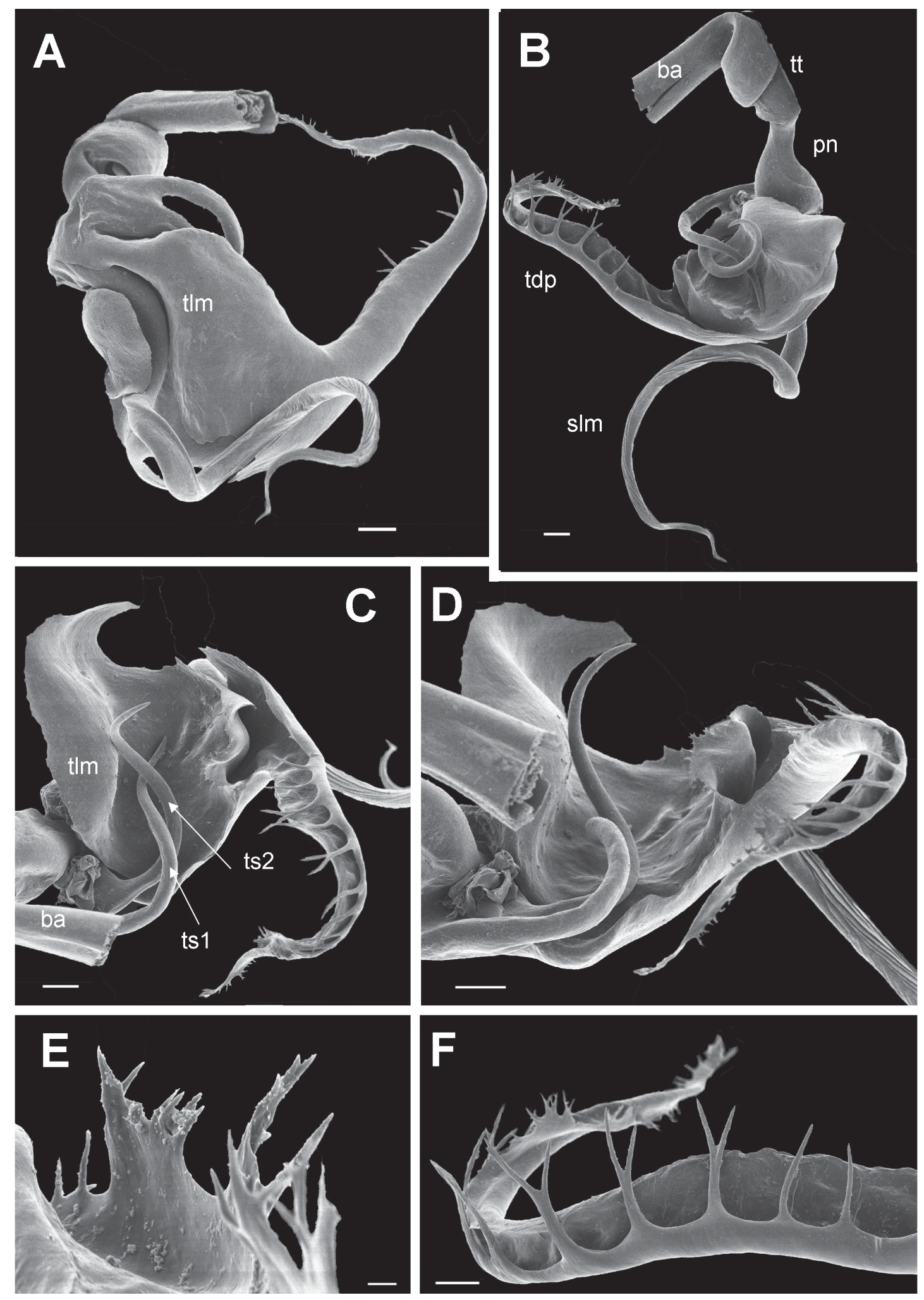

Fig. 6. Yia geminispina gen. et sp. nov., holotype. Left gonopod telopodite. A. Posterior, slightly basal view. B. Anterior, slightly basal view. C. Anterior, slightly basal view. D. Basal view. E-F. Detail of margin of telomere. F. Tip of telomere. Abbreviations: $b a=$ basomere, $p n=$ post-torsal narrowing, $s l m=$ solenomere, $t d p=$ telomeral distal process, $t l m=$ telomere, $t s 1, t s 2=$ telomeral spines, $t t=$ torsotope. Scales: $\mathrm{A}-\mathrm{D}=$ $0.1 \mathrm{~mm} ; \mathrm{F}=0.05 \mathrm{~mm} ; \mathrm{E}=0.005 \mathrm{~mm}$. 


\section{Description (male)}

SizE. Length ca $4 \mathrm{~cm}$, diameter $2.6 \mathrm{~mm}, 49$ podous rings, no apodous rings in front of telson.

Colour. Faded, very faint traces of a broad, light dorsal stripe.

HEAD. Without peculiarities.

ColLum. With a marginal and a submarginal furrow.

Body RINGs (Fig. 5A). Almost perfect cylinders, not vaulted; suture with an extended, shallow anteriad sinus below ozopore level; ozopores ca three diameters behind suture.

ANAL VALves. Each with a long, curved dorsal spine; marginal rim slightly raised, setiferous tubercles slightly protruding in a laterad direction (i.e., on very small 'ravelins').

OzOPORES. Starting from ring 6 .

LimBus (Fig. 5E). With simple, slender-triangular lobes. Surface of lobes longitudinally microstriate.

MALE LEGS. With postfemoral and tibial ventral pads in anterior half of body, except for first few legpairs.

Gonopod coxa (Fig. 5B-D). Slender and almost parallel-sided in anterior view. Proplica ( $p p$ ) simple, proplical lobe $(\mathrm{prl})$ not covered. Metaplica $(\mathrm{mp})$ with low, right-angled flange $(\mathrm{mf})$, above arculus with transverse shelf $(m s)$, laterally with triangular process $(l p)$, apically forming a small hood, or cucullus $(\mathrm{cu})$. A curved spine $(m s p)$ originating between $m s$ and $c u$.

Gonopod telopodite (Fig. 6). Arculus $90^{\circ}$. Torsotope ( $t t$ ) simple, compact, without processes (Fig. 6B). Posttorsal narrowing $(p n)$ without processes or spines. Telopodite just distal to posttorsal narrowing dividing into solenomere and telomere. Solenomere $(\mathrm{slm})$ long, simple, whiplike, ca as long as telomere. Proximal part of telomere $(\mathrm{tlm})$ roughly broadly triangular; two very long, curved spines $(t s 1, t s 2)$ arising from small lobe on basal side of telomere, close to the origin of the solenomere; distal part of telomere drawn out into very long, very slender process $(t d p)$, one edge of $t d p$ with a row of long, Y- or I-shaped spikes; tip of $t d p$ complicated micro-spinose.

\section{Distribution and habitat}

Known only from the type locality.

\section{Coexisting species}

No other odontopygids were present in the sample containing the unique holotype, but a number of other species have been recorded from Udzungwa Scarp F.R.: Chaleponcus circumvallatus Enghoff, 2014, C. hamerae Enghoff, 2014, C. nikolajscharffi Enghoff, 2014, Aquattuor sterosathe Enghoff, 2015, A. udzungwensis Enghoff, 2015, Prionopetalum asperginis Enghoff, 20XX and Casuariverpa scarpa gen. et sp. nov.

Utiliverpa gen. nov.

urn:1sid:zoobank.org:act:08065174-5A9C-4BFF-8604-653D4FF6D42C

\section{Type species}

Utiliverpa decapsulatrix gen. et sp. nov.

\section{Other included species}

None. 


\section{Diagnosis}

A genus of Odontopygidae-Prionopetalini characterized by: a long basad metaplical spine ( $m s p$ ) on the anterior side of the coxa - a compact torsotope $(t t)$ - lack of pretorsal or torsal spines/processes - a pronounced posttorsal narrowing without spines - a division of the telopodite into solenomere $(\mathrm{s} / \mathrm{m})$ and telomere $(\mathrm{tlm})$ immediately distal to posttorsal narrowing - a spine $(p s)$ emerging from the base of the solenomere - a ribbonlike solenomere which is accommodated in the concavity of the telomere and which apically is divided into a long hook and a subapical pointed lobe.

\section{Etymology}

From Latin utilis: useful, and verpa: penis. Refers to the shape of the solenomere which resembles a very useful instrument: a bottle-opener. Gender feminine.

\section{Remarks}

In the key of Kraus (1966) U. decapsulatrix gen. et sp. nov. runs to Rhamphidarpoides Kraus, 1960. This genus has been a repository for a number of quite different species, but was given a more strict definition by Frederiksen \& Enghoff (2015). The new species does not fit the definition of Rhamphidarpoides s.s., nor of Raduliverpa Frederiksen \& Enghoff, 2015, which was erected to accommodate several species formerly assigned to Rhamphidarpoides. I therefore propose a new genus here, but leave the question open whether some of the species "orphaned" from Rhamphidarpoides by Frederiksen \& Enghoff (2015) might belong here.

Utiliverpa decapsulatrix gen. et sp. nov. urn:Isid:zoobank.org:act:559C22A7-AE92-4633-AB61-788EADDC9AE3

Fig. 7

\section{Diagnosis}

(redundant, genus monotypic)

\section{Etymology}

The name is a Latin noun meaning "remover of capsules", cf. etymology of genus.

Material studied (total: 1 ふ)

\section{Holotype}

TANZANIA: $\widehat{\jmath}$, Morogoro Region, Kilombero District, Udzungwa Mts, Mwanihana Forest Reserve, near Sanje village, under rotten log in forest, K.M.Howell leg., KMH 1686 (VMNH).

\section{Description (male)}

SIzE. Length ca $6 \mathrm{~cm}$, diameter $3.9 \mathrm{~mm}, 67$ podous rings, no apodous rings in front of telson.

Colour. Specimen faded, traces of a broad, light dorsal stripe. Colour according to the collector's field notes: "dark, shiny black with brown stripe length of back; legs pale".

HEAD. Without peculiarities.

Collum. With a marginal and a submarginal furrow.

BoDY RINGS. Almost perfect cylinders, not vaulted; suture straight; ozopores ca three diameters behind suture.

ANAL VALVES. Each with a short, curved dorsal spine and a small ventral denticle; marginal rim slightly raised, setiferous tubercles hardly protruding. 
OzOPORES. Starting from ring 6.

LimBus (Fig. 7I). With simple, long-triangular lobes. Surface of lobes longitudinally microstriate.

MALE LeGs. With postfemoral and tibial ventral pads on legs, except a few anteriormost and posteriormost pairs, pads gradually decreasing in size towards posterior end.
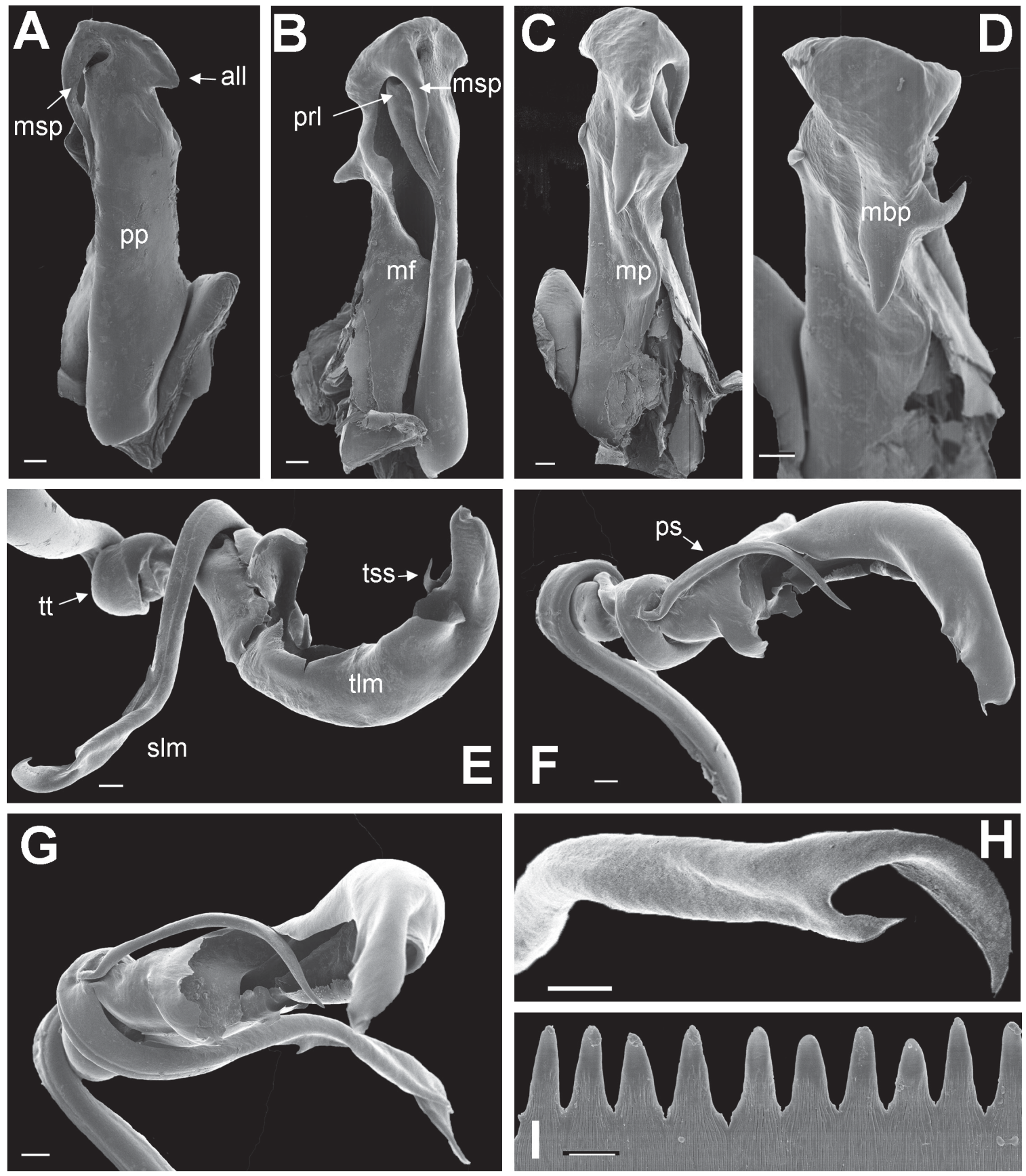

Fig. 7. Utiliverpa decapsulatrix gen. et sp. nov., holotype. A-D. Right gonopod coxa. A. Anterior view. B. Mesal view. C. Posterior view. D. Posterior-apical view. E-H. Left gonopod telopodite. E. Anterior view. F. Posterior view. G. Mesal-anterior-apical view. H. Solenomere. I. Limbus. Abbreviations: All = apical lateral lobe of coxa, $m b p=$ metaplical bifid process, $m f=$ metaplical flange, $m p=$ metaplica, $\mathrm{msp}=$ metaplical spine, $p r l=$ proplical lobe, $p p=$ proplica, $p s$ proximal solenomeral spine, $s l m=$ solenomere, $t l m=$ telomere, $t s s=$ telomeral subapical spike, $t t=$ torsotope. Scales: A-H $=0.1 \mathrm{~mm} ; \mathrm{I}=0.01 \mathrm{~mm}$. 
GoNOPOD COXA (Fig. 7A-D). In anterior view parallel-sided, ca $4 \frac{1}{2}$ times as long as broad, subapically with a lateral triangular incision delimiting an apical lateral lobe (all). Proplica $(p p)$ simple, parallel-sided; proplical lobe $(\mathrm{prl})$ in anterior view hidden behind metaplical spine. Metaplica $(\mathrm{mp})$ apically rounded, with a large mesal flange $(\mathrm{mf})$ closing basal part of space between pro- and metaplica, subapically with a long basad spine $(m s p)$ covering proplical lobe and a stout, bifid process $(m b p)$ on posterior surface.

Gonopod telopodite (Fig. 7E-H). Arculus $90^{\circ}$. Torsotope $(t t)$ simple, compact, without processes (Fig. 4B). Posttorsal narrowing without processes or spines. Telopodite just distal to posttorsal narrowing dividing into slender solenomere and broader telomere. Solenomere $(\mathrm{slm}) \mathrm{ca}$ as long as and normally resting within concavity of telomere (projecting perpendicularly on Fig. 7E due to shrinkage during preparation for SEM), simple, apically with a stout hook and a subapical pointed lobe, in profile strongly reminding of a kind of bottle-opener (e.g., http://www.barleypop.com/best-beer-bottle-opener-period/). A long, slender, curved spine ( $p s$ ) arising near base of solenomere. Telomere forming a curved, roughly parallel-sided trough, vaguely boat- or pod-shaped, with a subapical spike (tss) and several complicated lamellae inside the concavity (Fig. 7G).

\section{Distribution and habitat}

Known only from the type locality. Habitat: forest (under log).

\section{Coexisting species}

No other odontopygid species were found in the same sample as the unique holotype, but three are known from Mwanihana Forest Reserve: Chaleponcus mwanihanensis Enghoff, 2014, Aquattuor major Enghoff, 2015 and A. submajor Enghoff, 2015.

\section{Discussion}

In a previous paper (Enghoff 2016a), I argued that due to the bewildering confusion about genus concepts in Odontopygidae and to the absence of any well-supported hypotheses of relationships within the family, a 'splitter' approach will probably serve best, at least at the present stage. This means that a considerable number of narrowly circumscribed genera need to be defined, an agenda already adhered to by, e.g., Frederiksen \& Enghoff (2015) and Enghoff (2016a). In the same spirit three new monotypic genera are described in the present paper. Including these, the number of described odontopygid species from the Udzungwa mountains is 33. A few additional species, belonging to (relatively) well-defined, known genera, are known to exist, and ongoing and planned field-work in the Udzungwas will certainly reveal many more.

\section{Acknowledgements}

Thanks are due to the Tanzanian authorities that granted permits for collecting in the Udzungwa Mountains, as well as to my colleagues at the Natural History Museum of Denmark for providing specimens, to Judith Winston and her colleagues at VMNH for access to a specimen in that museum, to Kim Howell \& Wilirk Ngalason (Dar-es-Salaam) for access to information from the former's field notes, and to Anders Illum for photography.

\section{References}

Attems C.G. 1914. Afrikanisiche Spirostreptiden nebst Überblick über die Spirostreptiden orbis terrarum. Zoologica Stuttgart 65-66, Schweizerbart, Sttuttgart.

Attems C. 1938. Diplopoden des Belgischen Congo. Polydesmoidea, 2. Nachtrag und Spirostreptoidea, 1. Nachtrag. Revue de Zoologie et de Botanique Africaines 31: 225-313. 
ENGHOFF H., Three new genera of Odontopygidae from the Udzungwa mountains

Enghoff H. 2014. A mountain of millipedes I: An endemic species-group of the genus Chaleponcus Attems, 1914, from the Udzungwa Mountains, Tanzania (Diplopoda, Spirostreptida, Odontopygidae). European Journal of Taxonomy 100: 1-75. http://dx.doi.org/10.5852/ejt.2014.100

Enghoff H. 2016a. A mountain of millipedes III: A new genus for three new species from the Udzungwa mountains and surroundings, Tanzania, as well as several 'orphaned' species previously assigned to Odontopyge Brandt, 1841 (Diplopoda, Spirostreptida, Odontopygidae). European Journal of Taxonomy 177: 1-19. http://dx.doi.org/10.5852/ejt.2016.177

Enghoff H. 2016b. A mountain of millipedes IV: Species of Prionopetalum Attems, 1909, from the Udzungwa mountains, Tanzania. With notes on "P." fasciatum (Attems, 1896) and a revised species key (Diplopoda, Spirostreptida, Odontopygidae). European Journal of Taxonomy 215: 1-23. http://dx.doi. org/10.5852/ejt.2016.215

Enghoff H. \& Frederiksen S.B. 2015. A mountain of millipedes II: The genus Aquattuor Frederiksen, 2013 - five new species from the Udzungwa Mountains and one from Mt. Kilimanjaro, Tanzania (Diplopoda, Spirostreptida, Odontopygidae). European Journal of Taxonomy 150: 1-25. http://dx.doi. org/10.5852/ejt.2015.150

Frederiksen S.B. \& Enghoff H. 2015. East African odontopygid millipedes 4: A restricted redefinition of the genus Rhamphidarpoides Kraus, 1960, a related new genus, five new species, and notes on solenomere function (Diplopoda; Spirostreptida; Odontopygidae). Zootaxa 3926: 541-560. http://dx.doi.org/10.11646/ zootaxa.3926.4.5

Hoffman R.L. 1991. What is Odontopyge? A solution to a long standing nomenclatorial enigma in the Diplopoda (Spirostreptida Odontopygidae). Tropical Zoology 4: 65-73.

Kraus O. 1960. Äthiopische Diplopoden I. Monographie der Odontopygidae-Odontopyginae (Diplopoda, Spirostreptoidea). Annalen van het Koninklijk Museum van Belgisch-Congo 82, Koninklijk Museum voor Midden Afrika, Tervuren.

Kraus O. 1966. Phylogenie, Chorologie und Systematik der Odontopygoideen (Diplopoda, Spirostreptomorpha). Abhandlungen der senckenbergischen naturforschenden Gesellschaft 512, Naturmuseum Senckenberg, Frankfurt am Main.

Marshall A.R., Jørgensbye H.I.O., Rovero F., Platts P.L., White P.C.L. \& Lovett J.C. 2010. The speciesarea relationship and confounding variables in a threatened monkey community. American Journal of Primatology 72: 325-336. http://dx.doi.org/10.1002/ajp.20787

VandenSpiegel D. \& Pierrard G. 2009. Révision du genre Prionopetalum (Odontopygidae, Diplopoda) et descriptions de nouvelles espèces d'Afrique de l'Est. Journal of Afrotropical Zoology 5: 149-163.

Manuscript received: 23 February 2016

Manuscript accepted: 16 March 2016

Published on: 12 August 2016

Topic editor: Rudy Jocqué

Desk editor: Kristiaan Hoedemakers

Printed versions of all papers are also deposited in the libraries of the institutes that are members of the EJT consortium: Muséum national d'Histoire naturelle, Paris, France; Botanic Garden Meise, Belgium; Royal Museum for Central Africa, Tervuren, Belgium; Natural History Museum, London, United Kingdom; Royal Belgian Institute of Natural Sciences, Brussels, Belgium; Natural History Museum of Denmark, Copenhagen, Denmark; Naturalis Biodiversity Center, Leiden, the Netherlands. 